The Bangladesh Veterinarian (2015) 32 (1) : 7 - 12

\title{
Retrospective study of diseases of cattle at Adamdighi Veterinary Hospital, Bogra
}

\author{
MN Islam*, JA Begum¹, YA Sarker2, S Aktar² and MH Sikder ${ }^{2}$ \\ Department of Livestock Services, Adamdighi Upazilla, Bogra, Bangladesh
}

\begin{abstract}
A retrospective epidemiological study was undertaken at the Adamdighi Veterinary Hospital, Bogra from January 2012 to December 2014 to determine the occurrence of cattle diseases. According to the diseases register, a total of 12403 sick animals were examined and 7208 cases of cattle diseases were identified. About $44.7 \%$ were parasitic, $37.8 \%$ general systemic affections, $14.2 \%$ infectious, $1.3 \%$ reproductive, $1.2 \%$ poisoning and $0.8 \%$ metabolic diseases. The common diseases were worm infestation $(34.2 \%)$, pneumonia $(8.7 \%)$, foot and mouth disease $(2.5 \%)$, mastitis $(1.9 \%)$, black quarter $(0.6 \%)$, haemorrhagic septicaemia $(0.5 \%)$, simple indigestion $(11.9 \%)$, diarrhoea $(11.7 \%)$, fever $(7.5 \%)$, navel ill $(2.6 \%)$, bloat $(2.0 \%)$, calf scour $(1.7 \%)$, organo-phosphorus poisoning $(1.2 \%)$, retained placenta $(0.8 \%)$ and abortion ( $0.6 \%)$. About 2397 cases $(33.3 \%)$ were in male and 4811 cases $(67.7 \%)$ in female. Animals aged between 1-3 $\left(\mathrm{A}_{2}\right)$ years had highest occurrences $(34.3 \%)$ of diseases but lowest $17.1 \%$ occurrences were in cattle between 8-15 years $\left(\mathrm{A}_{4}\right)$ of age. Disease occurrence was higher $(37.3 \%)$ in summer (March - June) followed by $(32.5 \%)$ rainy (July - October) and lowest $(30.3 \%)$ in winter season (November - February). Gastrointestinal diseases $(n=3665)$ were most common but lower cases of hematopoietic system were identified $(n=107)$. This study showed the pattern of diseases that might help to identify the risk factors of these maladies in this area. (Bangl. vet. 2015. Vol. 32, No. $1,7-12)$
\end{abstract}

\section{Introduction}

Bangladesh is an agrarian country, and livestock has been an important component of farming for centuries. The contribution of livestock to the Gross Domestic Product (GDP) is about $1.7 \%$ (BBS, 2015). Most of the animals are in poor body condition, and have low productivity due to poor management and disease. These are among the most important factors slowing its development.

The management of animals and climate of Bangladesh are favourable for the occurrence of various diseases (Onneshan, 2014). Upazilla (sub-district) Veterinary Hospitals are reliable sources of information about animal diseases. Analysis of case records gives a picture of the disease problems of that local area. Reports on clinical

\footnotetext{
${ }^{1}$ Departments of Pathology Faculty of Veterinary Science, Bangladesh Agricultural University, Mymensingh-2202, Bangladesh

2Departments of Pharmacology, Faculty of Veterinary Science, Bangladesh Agricultural University, Mymensingh-2202, Bangladesh

*Corresponding authors:- E-mail: nazrul84bau@gmail.com
} 
case are available from Bangladesh Agricultural University Veterinary Teaching Hospital (Das and Hashim, 1996; Samad, 2001; Samad et al., 2002; Ali et al., 2011; Sarker et al., 2013; Sarker et al., 2015), Haluaghat Upazilla Veterinary Hospital, Mymensingh (Sarker et al., 1999) and Dairy Cooperatives in Pabna district (Pharo, 1987), Ulipur Upazilla Veterinary Hospital, Kurigram (Kabir et al., 2010), Chandanaish Upazilla of Chittagong (Pallab et al., 2012) and Patuakhali Science and Technology University Veterinary Clinic (Rahman et al., 2012). No case records are analysed in Bogra region. This study was undertaken to categorize the diseases in cattle presenting at the Upazilla Veterinary Hospital, Adamdighi, Bogra from January 2012 to December 2014.

\section{Materials and Methods}

\section{Sources and nature of data}

The retrospective epidemiological study of diseases in cattle was done using three years data at Upazilla Veterinary Hospital, Adamdighi, Bogra, from January 2012 to December 2014, and analysed to determine the occurrence of diseases, with seasonal pattern and distribution. Among the cases $(n=12403) 7208$ diseased cattle were studied.

\section{Data processing}

The data were checked manually for any error and analysed using Statistical Package for Social Science (SPSS) software 20 version. Chi-square test was used to compare different groups. Three seasons were considered, summer from March to May, rainy from June to October and winter from November to February (Ali et al., 2011).

\section{General, physical and clinical examinations}

Veterinary surgeons recorded the physical condition, behaviour, posture, gait, superficial skin wound, salivation, nasal discharge, distension of the abdomen, locomotive disturbance etc.

Different parts and systems of the body of each of the sick animals were examined following the procedure of palpation, percussion, auscultation, needle puncture and walking of the animals.

Temperature, pulse, and respiratory rate from each animal were recorded. According to the individual case, disease history, owner's complaints were recorded. Microscopic examination of faeces, blood, urine, skin scraping were carried out if appropriate, as described by Rosenberger (1979) and Samad et al. (1988).

\section{Results and Discussion}

Out of 12403 cases, 7208 (58.1\%) were cattle, of which 2397 (33.3\%) were male and $4811(67.7 \%)$ female. 
Occurrence of diseases and disorders in cattle are shown in Table 1 . About $44.7 \%$ were parasitic, $37.8 \%$ general systemic affections, $14.2 \%$ infectious, $1.3 \%$ reproductive, $1.2 \%$ poisoning and $0.8 \%$ metabolic diseases.

The 3227 affected with parasitic infection were categorised as worm (34.2\%), ectoparasites $(9.8 \%)$ and babesiosis $(0.7 \%)$ (Table 1$)$.

Table 1: Occurrence of diseases in cattle at the Upazilla Veterinary Hospital, Adamdighi, Bogra from January 2012 to December 2014

\begin{tabular}{|c|c|c|c|c|c|}
\hline $\begin{array}{c}\text { Type of diseases/ } \\
\text { disorders }\end{array}$ & $\begin{array}{l}\text { Diseases/ } \\
\text { disorders }\end{array}$ & $\begin{array}{c}\text { Number of cattle } \\
\text { affected }(\mathrm{n}=7208)\end{array}$ & \begin{tabular}{|c|} 
Percentage \\
$(\%)$
\end{tabular} & Total & $\begin{array}{c}\text { Percentage } \\
(\%)\end{array}$ \\
\hline \multirow[t]{3}{*}{ Parasitic diseases } & Worm infection & 2468 & 34.2 & 3227 & 44.7 \\
\hline & $\begin{array}{l}\text { Ectoparasite } \\
\text { infestation }\end{array}$ & 706 & 9.8 & & \\
\hline & Babesiosis & 53 & 0.7 & & \\
\hline \multirow{5}{*}{$\begin{array}{l}\text { Infectious } \\
\text { diseases }\end{array}$} & FMD & 183 & 2.5 & 1027 & 14.2 \\
\hline & HS & 39 & 0.5 & & \\
\hline & $\mathrm{BQ}$ & 45 & 0.6 & & \\
\hline & Pneumonia & 624 & 8.7 & & \\
\hline & Mastitis & 136 & 1.9 & & \\
\hline \multirow[t]{2}{*}{ Reproductive } & Retained placenta & 56 & 0.8 & 97 & 1.3 \\
\hline & Abortion & 41 & 0.6 & & \\
\hline Metabolic & Milk fever & 54 & 0.8 & 54 & 0.8 \\
\hline \multirow{7}{*}{$\begin{array}{l}\text { General systemic } \\
\text { affections }\end{array}$} & Navel ill & 189 & 2.6 & 2717 & 37.8 \\
\hline & Calf scour & 123 & 1.7 & & \\
\hline & Fever & 538 & 7.5 & & \\
\hline & Simple indigestion & 855 & 11.9 & & \\
\hline & Diarrhoea & 845 & 11.7 & & \\
\hline & Blot/Tympani & 143 & 2.0 & & \\
\hline & Skin diseases & 24 & 0.3 & & \\
\hline Poisoning & $\begin{array}{l}\text { Organo- } \\
\text { phosphorus } \\
\text { poisoning }\end{array}$ & 86 & 1.2 & 86 & 1.2 \\
\hline
\end{tabular}

Common infectious diseases included pneumonia (8.7\%), foot and mouth disease $(2.5 \%)$, mastitis $(1.9 \%)$, black quarter $(0.6 \%)$ and haemorrhagic septicaemia $(0.5 \%)$. Other conditions included simple indigestion (11.9\%), diarrhoea $(11.7 \%)$, fever $(7.5 \%)$, navel ill $(2.6 \%)$, bloat $(2.0 \%)$, calf scour $(1.7 \%)$ and organo-phosphorus poisoning $(1.2 \%)$. In addition, cases of retained placenta $(0.8 \%)$, abortion $(0.6 \%)$ and milk fever $(0.8 \%)$ were diagnosed. 
Cattle of all ages were affected with gastrointestinal diseases (Table 2). Cattle of 1-3 $\left(A_{2}\right)$ years old were more numerous than other age groups.

Table 2: Age, sex and season distribution of diseases in different systems of cattle at Adamdighi Upazilla, Bogra from January 2012 to December 2014

\begin{tabular}{|c|c|c|c|c|c|c|c|c|c|c|}
\hline \multirow[t]{2}{*}{ System affected } & \multicolumn{4}{|c|}{ Age of Cattle } & \multicolumn{2}{|c|}{ Sex } & \multicolumn{3}{|c|}{ Season } & \multirow[t]{2}{*}{ Total } \\
\hline & $\begin{array}{c}0-1 \\
\left(\mathrm{~A}_{1}\right)\end{array}$ & $\begin{array}{l}1-3 \\
\left(\mathrm{~A}_{2}\right)\end{array}$ & $\begin{array}{c}3-8 \\
\left(\mathrm{~A}_{3}\right)\end{array}$ & $\begin{array}{l}8-15 \\
\left(\mathrm{~A}_{4}\right)\end{array}$ & Male & Female & Summer & Rainy & Winter & \\
\hline Digestive & 711 & 1256 & 1072 & 625 & 1210 & 2455 & 1366 & 1190 & 1109 & 3665 \\
\hline GSA* & 275 & 486 & 414 & 242 & 470 & 947 & 528 & 460 & 429 & 1417 \\
\hline Musculo-integument & 190 & 336 & 286 & 167 & 331 & 648 & 365 & 318 & 296 & 979 \\
\hline Respiratory & 121 & 214 & 182 & 106 & 209 & 415 & 233 & 203 & 189 & 624 \\
\hline Reproductive & 45 & 80 & 68 & 40 & 79 & 154 & 87 & 76 & 71 & 233 \\
\hline Multiple system & 36 & 63 & 54 & 31 & 61 & 122 & 68 & 59 & 55 & 183 \\
\hline Haematopoietic & 21 & 37 & 31 & 18 & 37 & 70 & 40 & 35 & 32 & 107 \\
\hline Total & 1399 & 2471 & 2108 & 1230 & 2397 & 4811 & 2686 & 2340 & 2182 & 7208 \\
\hline Percentage (\%) & 19.3 & 34.3 & 29.3 & 17.1 & 33.3 & 66.7 & 37.3 & 32.5 & 30.3 & \\
\hline
\end{tabular}

*General Systemic Affections

Age, sex and seasonal variations of diseases and disorders in cattle are presented in Table 2. Female cattle $(66.7 \%)$ were more numerous than males (33.3\%). Gastrointestinal diseases $(n=3665)$ were most common, and mostly female cattle were affected where poor veterinary health care, particularly strategic parasitic control was lacking (Rahman et al., 2012).

Temporal distribution of the diseases is shown in Fig. 1 during January 2012 to June 2015 where highest occurrence of diseases was found in March $(n=720)$ followed by May $(n=693)$ and lowest in February $(n=475)$. Banu et al. $(2015)$ reported the highest occurrence of diseases in cattle in summer $(47.9 \%)$ followed by rainy $(30.1 \%)$ and in winter seasons $(22.0 \%)$, which is similar to these observations.

Temporal distribution of the diseases/disorders

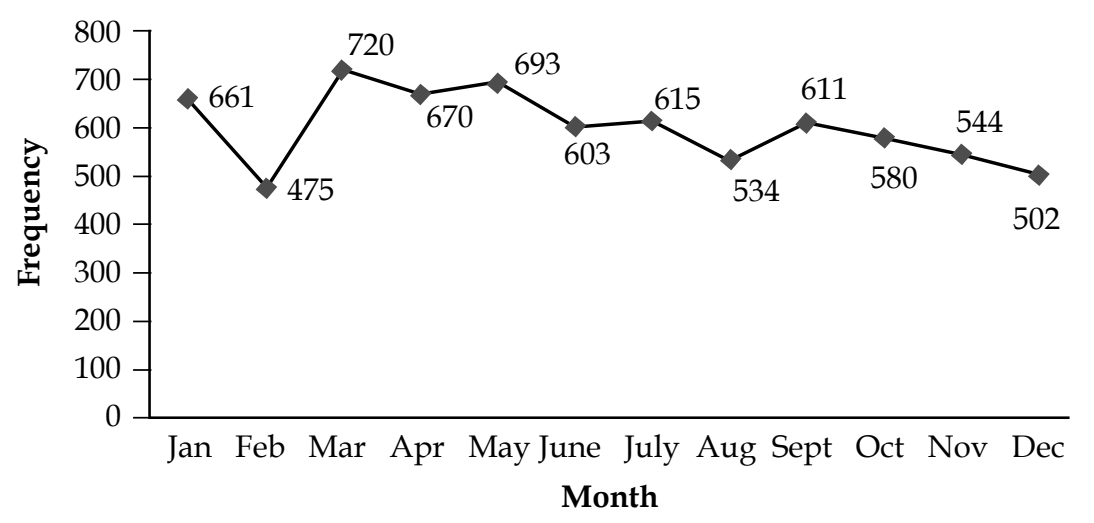

Fig. 1. Graphical representation of temporal distribution of diseases and disorders in cattle at Adamdighi Upazilla, Bogra from January 2012 to December 2014. 
There is statistically significant relation between diseases and ages of cattle $\left(x^{2}=359.507\right)$, disease and sex $\left(x^{2}=389.313\right)$ and disease and season $\left(x^{2}=39.451\right)$.

\section{Conclusions}

The occurrence of the diseases was higher in female than male. Animals aged between 1-3 years are more likely to be affected by the diseases and disorders. More diseases were reported in the summer season. Gastrointestinal diseases were more common. Retrospective epidemiological analysis for a period of 3 years or more will help to identify risk factors of diseases for developing future control measures.

\section{Acknowledgements}

The authors are grateful to staff of Upazilla Veterinary Hospital, Adamdighi, Bogra, Bangladesh for their support and help.

\section{References}

Ali MH, Bhuiyan MKJ, Alam MM 2011: Retrospective epidemiologic study of diseases in ruminants in Khagrachari hill tract district of Bangladesh. Bangladesh Journal of Veterinary Medicine 9 145-153.

Bangladesh Bureau of Statistics (BBS), 2015: www.bbs.gov.bd

Banu JMS, Hoque MF, Badruzzaman ATM, Kawser HM 2015: Bovine diseases at Dinajpur district of Bangladesh: Epidemiological status with relation to age and season. Annals of Veterinary and Animal Science 2 55-63.

Blood DC, Radostits OM 1989: Veterinary Medicine, $7^{\text {th }}$ edn., Balliere and Tindal, London.

Blood DC, Rodistis OM 2000: Veterinary Medicine. 9th edn., WB Sounders Co. Ltd., London.

Das BC, Hashim MA 1996: Studies on surgical affections in calves. Bangladesh Veterinary Journal 30 53-57.

Kabir MH, Reza MA, Razi KMA, Parvez MM, Bag MAS, Mahfuz SU 2010: A report on clinical occurance of diseases and disorders in cattle and goat at the Upazilla Veterinary Hospital, Ulipur, Kurigram. International Journal of Biological Research 2 17-23.

Onneshan U 2014: Recent Trends of Growth in Agriculture, Industry and Power. Bangladesh Economic Update, Dhaka, Bangladesh.

Pallab MS, Ullah SM, Uddin MM and Miazi OF 2012: A cross sectional study of several diseases in cattle at Chandanaish Upazilla of Chittagong district. Scientific Journal of Veterinary Advances 1 28-32.

Pharo HJ 1987: Analysis of clinical case records from dairy co-operatives in Bangladesh. Tropical Animal Health and Production 19 136-142. 
Rahman MA, Islam MA, Rahman MA, Talukder AK, Parvin MS, Islam MT 2012: Clinical diseases of ruminants recorded at the Patuakhali Science and Technology University Veterinary Clinic. Bangladesh Journal of Veterinary Medicine 10 63-73.

Rosenberger G 1979: Clinical examination of Cattle, $2^{\text {nd }}$ edn., Varlag Paul Parey, Berlin, Germany.

Samad MA 2001: Observations of clinical diseases in ruminants at the Bangladesh Agricultural University Veterinary Clinic. Bangladesh Veterinary Journal 35 93-120.

Samad MA 2008: Animal Husbandry and Veterinary Science. $1^{\text {st }}$ Publication, LEP Publication No. BAU Campus, Mymensingh, Bangladesh.

Samad MA, Bari ASM, Bashar SA 1988: Gross and histopathological studies on bovine babesiosis in Bangladesh. Indian Journal of Animal Science 58 926-928.

Samad MA, Islam MA, Hossain A 2002: Patterns of occurrence of calf diseases in the district of Mymensingh in Bangladesh. Bangladesh Veterinary Journal 36 1-5.

Sarker MAS, Aktaruzzaman M, Rahman AKMA, Rahman MS 2013: Retrospective study of clinical diseases and disorders of cattle in Sirajganj district in Bangladesh. Bangladesh Journal of Veterinary Medicine 11 137-144.

Sarker MAS, Hashim MA, Rahman MB, Begum H 1999: Studies on occurrence of diseases of animals (medicinal and surgical) in a Thana of Bangladesh. Progressive Agriculture 10 165-167.

Sarker YA, Miah AH, Sharif N, Himel MH, Islam S, Ray RC, Paul TK, Islam MT, Sikder MH 2015: A retrospective study of common diseases at Veterinary Teaching Hospital, Bangladesh Agricultural University, Mymensingh. Bangladesh Journal of Veterinary Medicine 13 55-61. 